\title{
Purification of Human C5a des arg by Immunoadsorbent and Molecular Sieve Chromatography ${ }^{1}$
}

\author{
George L. Manderino *, Adoracion F. Suarez *, Steven L. Kunkel **, \\ Peter A. Ward **, Arthur A. Hirata * and Henry Showell ${ }^{* * *}$ \\ * Laboratory of Immunology, Abbott Laboratories, North Chicago, IL 60064, ** Department of Pathology, \\ University of Michigan Medical School, Ann Arbor, MI 48109, and *** Department of Immunology and \\ Infectious Diseases, Pfizer Research, Croton, CT 06340 (U.S.A.)
}

Human C5a des arg was isolated from complement-activated serum by immunoadsorption followed by Sephadex G-75 chromatography. C5a des arg obtained by this 2-step procedure was shown to be immunologically identical to C5a des arg purified by a conventional multi-step method, homogeneous on SDS-polyacrylamide gels, and biologically active. Although this technique yields approximately the same amount of $\mathrm{C} 5 \mathrm{a}$ des arg/liter of activated serum as that obtained by conventional methods, its simplicity and relative rapidity make it a practical alternative.

Key words: human complement C5a - complement purification - chemotaxis

\section{Introduction}

Activation of complement by either the classical or alternate pathway generates peptides with diverse biological activities. The C5a molecule, generated from complement component $\mathrm{C} 5$, has a variety of important phlogistic activities including: contraction of smooth muscle, histamine release from mast cells, increased vascular permeability (Cochrane and Müller-Eberhard, 1968; Shin et al., 1968; Vogt, 1968), leukocyte chemotaxis (Ward and Newman, 1969; Chenoweth and Hugli, 1980), lysosomal enzyme secretion (Goldstein et al., 1973; Goldstein and Weissmann, 1974; Henson et al., 1978), leuko-aggregation (Craddock et al., 1977), and stimulation of leukocytic oxidative metabolism (Goetzl et al., 1974; Goldstein et al., 1975). However, carboxypeptidase activity present in serum rapidly cleaves the $\mathrm{COOH}$-terminal arginine from C5a (Bokisch et al., 1969) and destroys virtually all of its anaphylactic function (Bokisch and Müller-Eberhard, 1970). The resulting peptide, C5a des arg, retains most other pro-inflammatory activities and is the predominant form of the C5 fragment found in complement-activated serum.

\footnotetext{
${ }^{1}$ Supported in part by NIH Grants HL 28442, HL 2809 and HL 26498.
} 
Both human C5a and C5a des arg have been purified to homogeneity and well characterized chemically (Fernandez and Hugli, 1976; Fernandez and Hugli, 1978; Gerard and Hugli, 1981). For most studies involving the biological activities of C5a and $\mathrm{C} 5 \mathrm{a}$ des arg complement-activated serum or serum fractions are used. Consequently it has been difficult to rule out the contribution of other serum proteins on the observed phenomena. In this report we describe a purification scheme for isolating milligram quantities of highly purified $\mathrm{C} 5 \mathrm{a}$ des arg from complementactivated human serum using immunoadsorbent and molecular sieve chromatography. This procedure is simpler and faster than conventional purification procedures (Vallota and Müller-Eberhard, 1973; Fernandez and Hugli, 1976; Fernandez and Hugli, 1978) and thus provides a practical alternative.

\section{Materials and Methods}

Preparation of human leukocytes

Leukocytes from healthy volunteers were isolated by dextran sedimentation using blood to which sodium heparin had been added (Manderino et al., 1981).

Preparation of serum

Outdated plasma was obtained from a local blood bank, converted to serum, and processed to remove clots and lipids as previously described (Manderino et al., 1981).

\section{Antiserum production}

Human C5a des arg was purified from serum by the method of Vallota and Müller-Eberhard (1973). Antibodies to C5a des arg were raised in a goat by multisite intramuscular injections of $50 \mu \mathrm{g}$ of $\mathrm{C} 5 \mathrm{a}$ des arg emulsified in complete Freund's adjuvant. The goat was boosted at 4 month intervals. Antiserum was collected 10 days after each $\mathrm{C} 5 \mathrm{a}$ des arg injection and $\mathrm{IgG}$ was isolated according to the method of Gray et al. (1969).

\section{Preparation of immunoadsorbent columns}

The IgG fraction of goat anti-C5a des arg was incubated with $200 \mathrm{ml}$ of CNBr-activated Sepharose 6B (10.2 $\mathrm{mg} \mathrm{IgG} / \mathrm{ml}$ Sepharose) overnight at $4^{\circ} \mathrm{C}$ (Cuatrecasas et al., 1968). The extent of coupling was determined to be $9.8 \mathrm{mg}$ $\mathrm{IgG} / \mathrm{ml}$ Sepharose $4 \mathrm{~B}$. The slurry was poured into a $5 \mathrm{~mm} \times 70 \mathrm{~mm}$ column and equilibrated with phosphate-buffered saline.

\section{Isolation of $\mathrm{C} 5$ a des arg}

Six liters of normal human serum were incubated at $37^{\circ} \mathrm{C}$ for $60 \mathrm{~min}$ with boiled yeast cells ( $20 \mathrm{~g} / 1)$ to activate complement (Vallota and Müller-Eberhard, 1973). The yeast was removed by centrifugation $(400 \times \mathrm{g}$ for $10 \mathrm{~min})$ and the serum was heat-inactivated for $30 \mathrm{~min}$ at $56^{\circ} \mathrm{C}$. The activated serum was applied to the Sepharose $6 \mathrm{~B}-$ anti-C5a des arg column at a flow rate of $100 \mathrm{ml} / \mathrm{h}$ at $4{ }^{\circ} \mathrm{C}$. The 
column was washed with 2 liters of PBS and the adsorbed material was eluted with $0.2 \mathrm{M}$ glycine- $\mathrm{HCl}$ buffer, $\mathrm{pH}$ 2.8. After dialysis in PBS the eluate was concentrated to $6 \mathrm{ml}$ using YM5 ultrafiltration (Amicon, Lexington, MA). Five milliliters of this concentrate were then applied to a $2.5 \mathrm{~cm} \times 93 \mathrm{~cm}$ Sephadex G-75 column calibrated with various molecular weight markers and eluted with PBS $(8 \mathrm{ml} / \mathrm{h})$. Fractions demonstrating chemotactic activity $(\sim 10-15,000$ daltons $)$ were pooled and concentrated by YM5 ultrafiltration.

\section{Chemotaxis assay}

Chemotaxis by human neutrophils under agarose was assayed as previously described (Manderino et al., 1981). In this assay, neutrophil migration distances in the presence or absence of chemoattractant were quantitated. Results were expressed as the chemotactic index $(\mathrm{CI})$, i.e. $\mathrm{A} / \mathrm{B}$, where $\mathrm{A}$ represents directed migration and $\mathrm{B}$ represents random migration. In the absence of a chemotactic gradient the $\mathrm{Cl}$ is unity. CI values greater than one are obtained in the presence of a chemotactic gradient.

\section{Lysosomal enzyme releasing activity}

Lysosomal enzyme release from human neutrophils was assessed by a modification of the procedure of Fantone et al. (1979). Two hundred microliters of human neutrophils $\left(2 \times 10^{7} \mathrm{cells} / \mathrm{ml}\right)$ in Hanks' balanced salt solution containing $0.1 \%$ ( $\mathrm{w} / \mathrm{v}$ ) bovine serum albumin and $5 \mu \mathrm{g} / \mathrm{ml}$ cytochalasin B (Aldrich Chemical Co., Milwaukee, WI) were added to tubes containing $40 \mu \mathrm{l}$ of C5a des arg or saline. After incubating for $10 \mathrm{~min}$ at $37^{\circ} \mathrm{C}$ the mixtures were centrifuged at $200 \times \mathrm{g}$ for $10 \mathrm{~min}$ at $4^{\circ} \mathrm{C}$. $\mathrm{N}$-acetyl- $\beta$-glucosaminidase activity was assayed by incubating $50 \mu \mathrm{l}$ of supernatant with $450 \mu \mathrm{l}$ of $4 \mathrm{mM}$-nitrophenyl-N-acetyl-B-D-glucosaminide (Sigma Chemical Co., St. Louis, MO) in $0.05 \mathrm{M}$ sodium citrate buffer for $2 \mathrm{~h}$ at $37^{\circ} \mathrm{C}$. The reaction was terminated by the addition of $500 \mu \mathrm{l}$ glycine- $\mathrm{NaOH}$ buffer $(0.4 \mathrm{M}, \mathrm{pH}$ 10.5) and absorbance was measured at $410 \mathrm{~nm}$.

\section{$S D S-P A G E$}

Analysis by SDS-polyacrylamide gel electrophoresis was performed using $7.5 \%$ cylindrical gels and the Weber and Osborn method (1969) under non-reducing conditions. Electrophoresis was performed at $7.5 \mathrm{~mA} / \mathrm{gel}$ for $4 \mathrm{~h}$ at room temperature. Gels were subsequently stained for protein using Coomassie blue or for carbohydrate using the PAS procedure as described by Segrest et al. (1971).

\section{Immunochemical analysis}

Ouchterlony immunodiffusion was performed in $1 \%$ agarose gels in PBS, pH 7.5. Five micrograms of antigen or $75 \mu \mathrm{g}$ of goat anti-human C5a des arg were added to $7 \mu \mathrm{l}$ wells and incubated for $24 \mathrm{~h}$ at room temperature. Immunoelectrophoresis was performed in $1 \%$ agarose in $0.04 \mathrm{M}$ barbital buffer, $\mathrm{pH} 8.6$, employing $5 \mu \mathrm{g}$ of antigen in $7 \mu \mathrm{l}$ wells and developed with $100 \mu \mathrm{l}$ of goat anti-human C5a des arg IgG (10 $\mathrm{mg} / \mathrm{ml}$ ). Human C5a des arg was prepared according to the method of Vallota and Müller-Eberhard (1973) and human C5 was purified as previously described (Kunkel et al., 1980). 


\section{Protein determinations}

Protein concentrations were determined by absorption at $280 \mathrm{~nm}$ and by a dye-binding assay (Bio-Rad Laboratories, Richmond, CA) using bovine gammaglobulin as the standard.

\section{Results}

\section{Purification of $\mathrm{C} 5 \mathrm{a}$ des arg}

Six liters of complement-activated serum were passed over a column containing $200 \mathrm{ml}$ of Sepharose anti-human C5a des arg. Monitored by its ability to stimulate neutrophil chemotaxis, C5a des arg was completely removed from the serum eluted from the immunoadsorbent. The serum fraction adsorbed to the column was subsequently eluted with glycine- $\mathrm{HCl}$ buffer. This material was dialyzed vs. PBS, concentrated by ultrafiltration and chromatographed on Sephadex G-75. As shown in Fig. 1, most of the protein eluted from this column in the 'fall through' region ( $\geqslant 75,000$ daltons) (peak I). Smaller peaks eluted in the region of 43,000 daltons (peak II) and 15,000 regions (peak III).

Each Sephadex G-75 fraction was analyzed for chemotactic activity to indicate the presence of C5a des arg. Only fractions in peak III exhibited significant activity (Fig. 1). Fractions in each of the 3 peaks were pooled and concentrated. Serial dilutions of these samples were assayed for C5a des arg-activity using both chemotaxis and induction of neutrophil lysosomal enzyme secretion. As summarized in

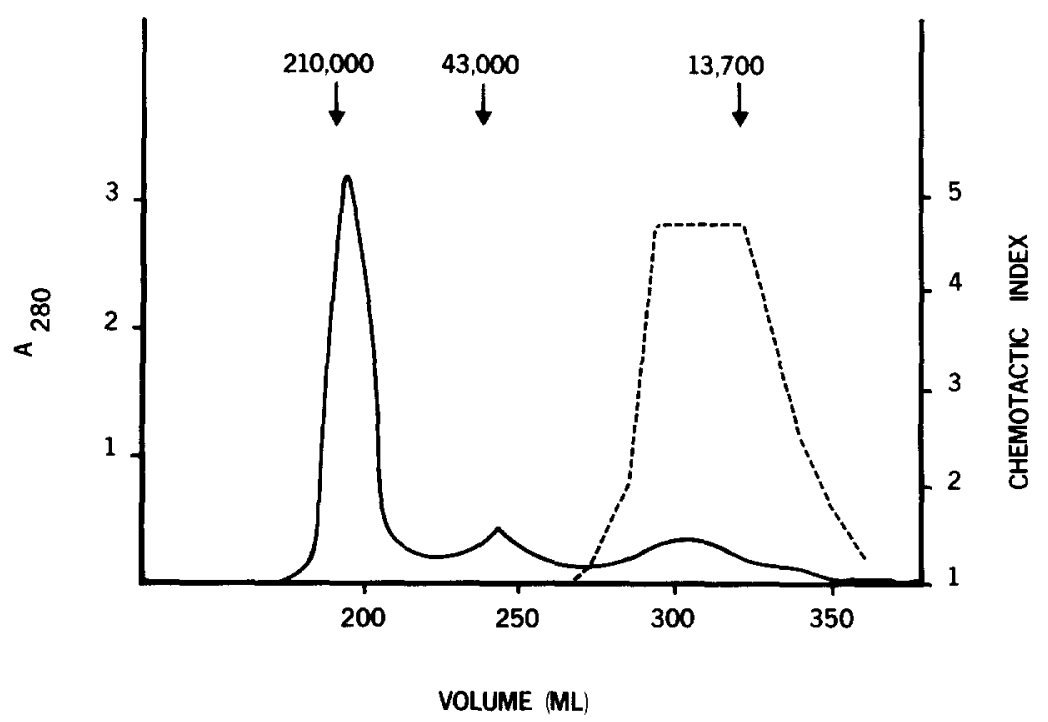

Fig. 1. Sephadex G-75 chromatography of the C5a des arg-enriched fraction obtained from complementactivated serum by Sepharose-anti-C5a immunoadsorption. ___ absorbance at $280 \mathrm{~nm} ;-. .--$, chemotactic activity. 
TABLE I

INDUCTION OF HUMAN NEUTROPHIL ACTIVITY BY C5A DES ARG-CONTAINING SERUM OR SERUM FRACTIONS

\begin{tabular}{|c|c|c|}
\hline Reagents $^{a}$ & $\begin{array}{l}\text { Glucosaminidase } \\
\text { activity }^{\mathrm{b}}\end{array}$ & $\begin{array}{l}\text { Chemotactic } \\
\text { index }\end{array}$ \\
\hline Buffer & 0.22 & 1.0 \\
\hline Normal serum & 0.33 & 1.2 \\
\hline Complement-activated serum & 1.18 & 5.1 \\
\hline $\begin{array}{l}\text { Complement-activated serum passes through the } \\
\text { immunoadsorbent column }\end{array}$ & 0.28 & 1.1 \\
\hline $\begin{array}{l}\mathrm{HCl} \text {-glycine eluted fraction of immunoadsorbed } \\
\text { complemented-activated serum }\end{array}$ & 1.21 & 5.0 \\
\hline G-75 peak I ( $\geqslant 75,000$ daltons) & 0.29 & 1.2 \\
\hline G-75 peak II ( $\sim 43,000$ daltons $)$ & 0.21 & 1.1 \\
\hline G-75 peak III ( $\sim 15,000$ daltons $)$ & 1.22 & 5.2 \\
\hline
\end{tabular}

${ }^{a}$ Buffer (Hanks' balanced salt solution), heat-inactivated normal human serum, and heat-inactivated yeast cell-activated human serum were used without dilution. All other reagents were adjusted to 100 $\mu \mathrm{g} / \mathrm{ml}$.

$b$ Means of triplicate determinations from 3 experiments with standard deviations of $\leqslant 2 \%$.

${ }^{c}$ Means of quadruplicate determinations from a representative experiment with standard deviations of $\leqslant 10 \%$.

Table I, only peak III demonstrated these biological activities associated with C5a des arg. Peak III will subsequently be referred to as immunoadsorbent-purified C5a des arg.

\section{Immunochemical analysis of immunoadsorbent-purified C5a des arg}

Immunoadsorbent-purified C5a des arg showed a line of identity with human C5a des arg purified by the method of Vallota and Müller-Eberhard (1973) when tested with goat anti-human C5a des arg by Ouchterlony immunodiffusion (Fig. 2). It is interesting to note that anti-C5a des arg did not react with purified $\mathrm{C} 5$ prepared by the method of Kunkel et al. (1980). Not surprisingly, anti-C5a des arg did react with C5a purified from zymosan-activated human serum in the presence of epsilon amino caproic acid (Vallota and Müller-Eberhard, 1973). In IEP experiments, immunoadsorbent-purified C5a des arg exhibited similar electrophoretic mobility as conventionally purified C5a des arg as revealed with anti-human C5a des arg (Fig. 3).

In addition to lacking biological activity, neither, peak I nor peak II was reactive with anti-C5a des arg in Ouchterlony and IEP analyses. Subsequent analysis of these peaks by IEP using anti-human serum revealed the presence of a total of 5 proteins. Using a panel of antisera to various human serum proteins, two have been identified, i.e. albumin and IgG.

SDS-PAGE of immunoadsorbent-purified C5a des arg

SDS-polyacrylamide gel electrophoresis was employed to determine the purity of immunoadsorbent-purified C5a des arg. As shown in Fig. 4, immunoadsorbent-puri- 


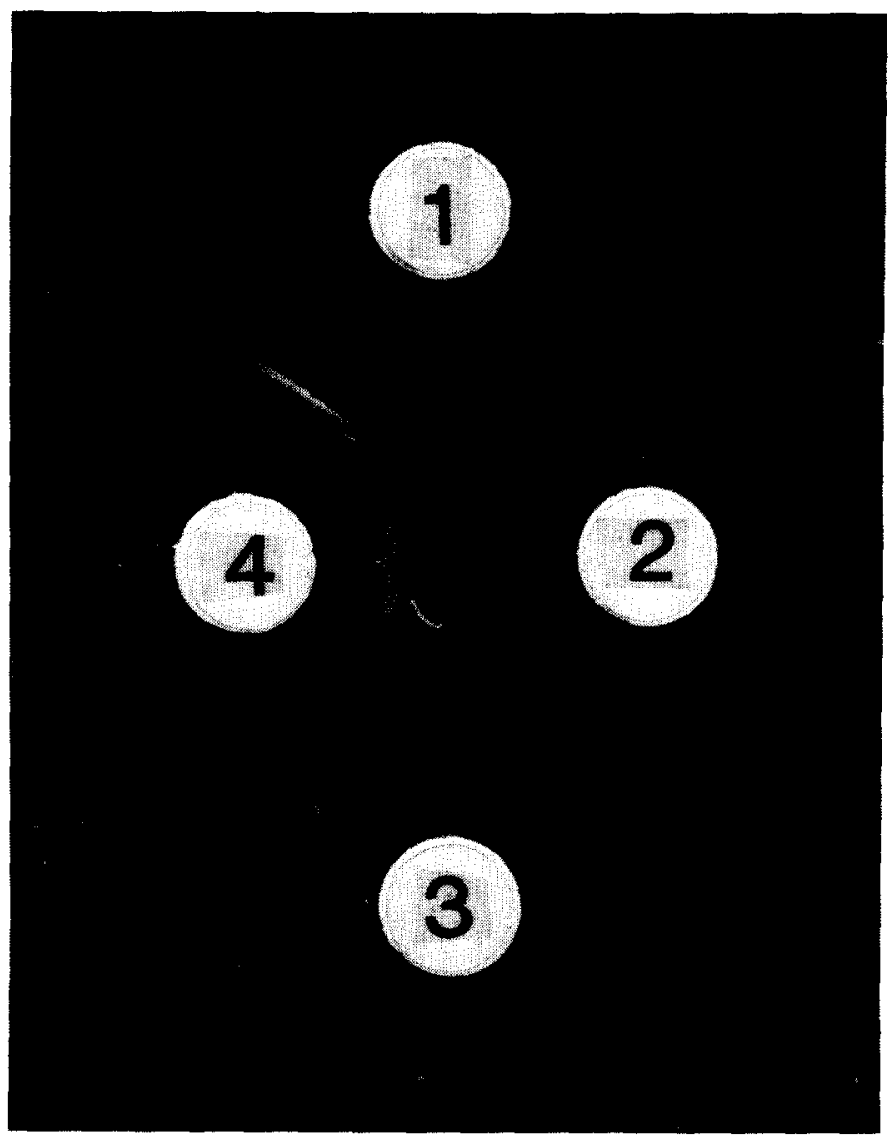

Fig. 2. Ouchterlony analysis of immunoadsorbent-purified human C5a des arg. Well no. 1, C5a prepared according to the method Vallota and Müller-Eberhard (1973); well no. 2, immunoadsorbent-purified C5a des arg; well no. 3, human C5; well no. 4, goat anti-human C5a des arg (IgG).

fied C5a des arg displayed a single band in 7.5\% SDS-polyacrylamide gels and stained for both carbohydrate and protein. The molecular weight was estimated using the method of Segrest and Jackson (1972) to be 14,600 daltons.

Yield of immunoadsorbent-purified C5a des arg

The yield of $\mathrm{C} 5 \mathrm{a}$ des arg at each purification step as appraised by chemotactic activity as well as lysosomal secretion of B-D-glucosaminidase is summarized on Table II. Twenty six percent of the chemotactic activity and $22 \%$ of the lysosomal secretion activity present in complement-activated serum remained in the purified $\mathrm{C} 5 \mathrm{a}$ des arg preparation. The latter fraction was concentrated by ultrafiltration to $6 \mathrm{ml}$. The final protein concentration was $0.94 \mathrm{mg} / \mathrm{ml}$ as determined by a dye-binding assay and 0.68 O.D. units $/ \mathrm{ml}$ as observed at $280 \mathrm{~nm}$ spectrophotometrically. 


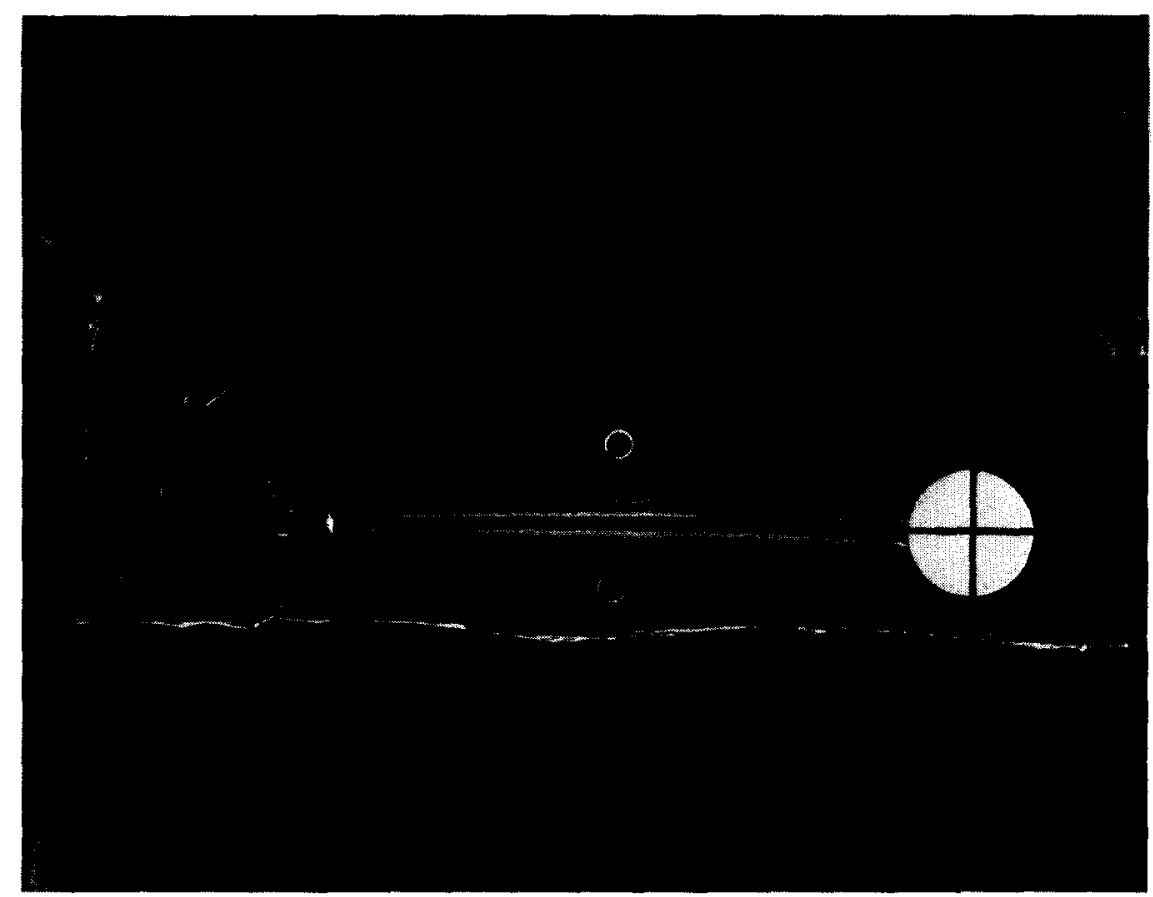

Fig. 3. Immunoelectrophoresis of immunoadsorbent-purified C5a des arg (top) and C5a des arg prepared as described by Vallota and Müller-Eberhard (1973) (bottom) developed with goat anti-human C5a des $\arg (\mathrm{IgG})$.

\section{TABLE II}

\section{SUMMARY OF C5A DES ARG PURIFICATION}

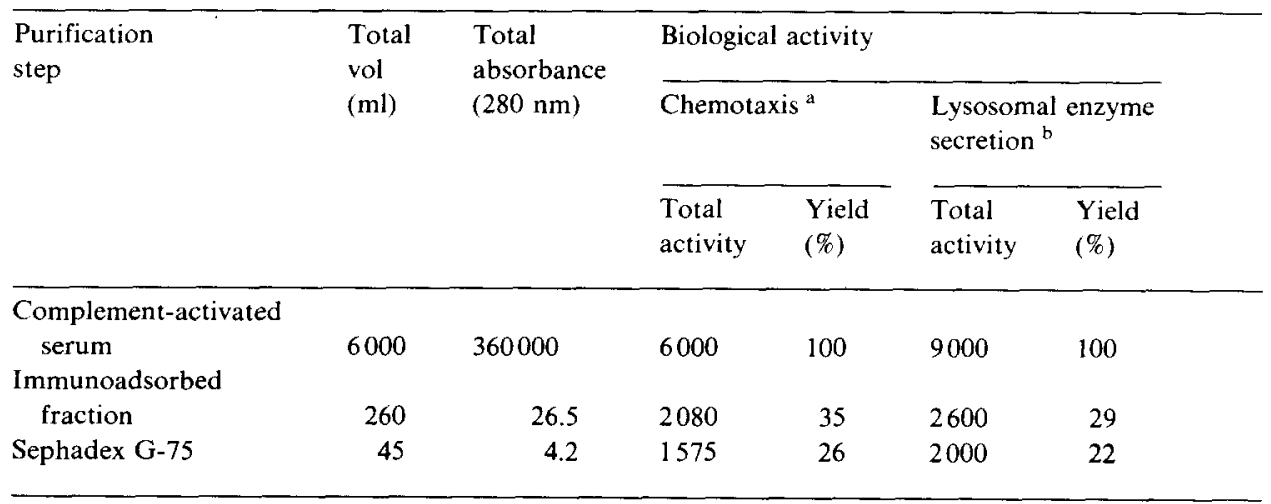

a Total activity is equal to the reciprocal of the dilution which elicits chemotactic indices of $>4.5$ multiplied by the total volume.

b Lysosomal enzyme secretion was determined by measuring lysosomal enzyme secretion of B-D-glucosaminidase. The total activity was determined by multiplying the dilution giving $\geqslant 0.30 . D .410 \mathrm{~nm}$ absorbance by the total volume. 


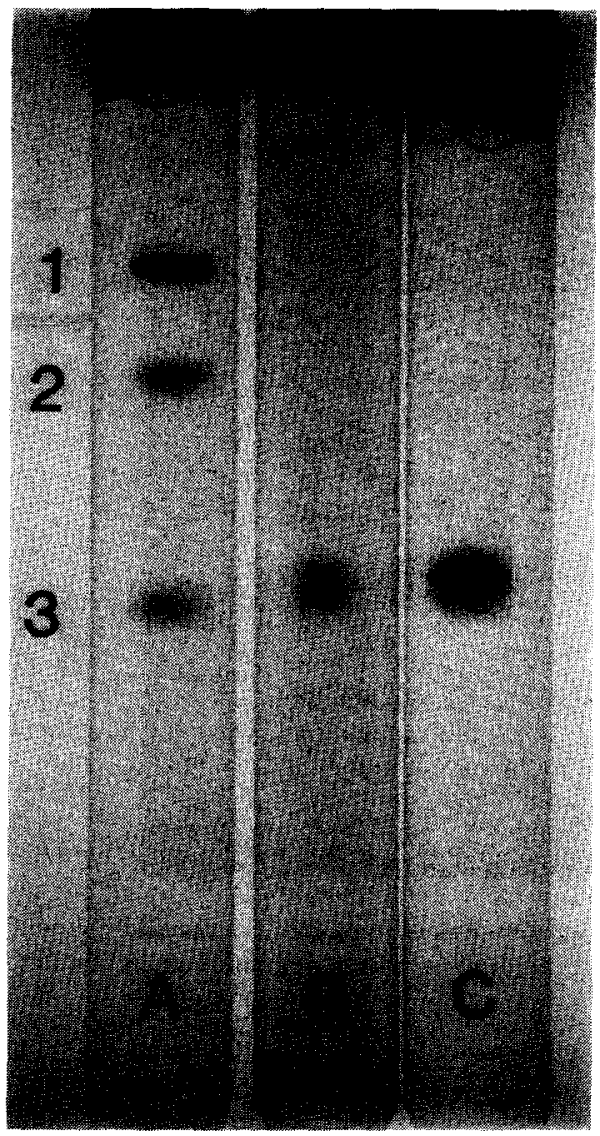

Fig. 4. SDS-polyacrylamide gel (7.5\%) analysis of immunoadsorbent-purified C5a des arg. A: standards stained for protein, (1) transferrin, 90,000 daltons; (2) ovalbumin, 43,000 daltons; (3) ribonuclease A. 13,700 daltons. B: C5a des arg stained for carbohydrate. C: C5a des arg stained for protein. Twenty micrograms of C5a were applied to $100 \mathrm{~mm} \times 5 \mathrm{~mm}$ gels.

\section{Discussion}

A combination of immunoadsorbent and molecular sieve chromatography has been employed to provide a rapid and simplified method for isolating milligram quantities of highly purified and biologically active human C5a des arg. Although other purification schemes have been described for isolating C5a and C5a des arg from complement-activated serum (Vallota and Müller-Eberhard, 1973; Fernandez and Hugli, 1976; Fernandez and Hugli, 1978) these methods are time-consuming and laborious. The method of Fernandez and Hugli (1978) for purifying C5a des arg from activated human serum, for example, involves 3 chromatographic columns, an acid and an ethanol extraction, 3 dialyses, and 2 lyophilizations. 
The C5a des arg purified by the simplified procedure described in this report was shown to be immunologically identical to C5a des arg purified by a conventional method (Vallota and Müller-Eberhard, 1973). In addition, the final preparation induced biological activities characteristic of C5a des arg, i.e., induction of neutrophil chemotaxis and lysosomal enzyme secretion. Twenty-six percent of the chemotactic activity and $22 \%$ of the lysosomal enzyme glucosaminidase secretion activity present in complement-activated serum was recovered in the purified C5a des arg fraction. Fernandez and Hugli (1978) have estimated that C5a des arg is present at $3.3 \mathrm{mg} /$ liter in activated serum. Our purified C5a des arg preparation contained $5.6 \mathrm{mg}$ protein from 6 liters of complement-activated serum representing a $28 \%$ yield, which is in close agreement with the yields calculated on the basis of functional activity (Table II). The good correlation between the yields of biological activity and protein indicates that the acidic conditions used to remove C5a des arg from the immunoadsorbent column did not affect its biological activity. This is consistent with the unusual structural stability of the C5a and the C5a des arg molecules (Hugli and Müller-Eberhard, 1978).

By chemical analysis the molecular weight of $\mathrm{C} 5 \mathrm{a}$ is approximately 11,000 daltons (Fernandez and Hugli, 1976). Because of its high carbohydrate content (25\%), C5a des arg, like many glycoproteins (Segrest et al., 1971), exhibits anomalous behavior in SDS-PAGE. This results in an overestimation of the molecular weight. Indeed, we estimated the molecular weight of our preparation to be 14,600 daltons which is similar to the estimates of 15-16,000 daltons from SDS-PAGE determined by other investigators (Vallota and Müller-Eberhard, 1973; Fernandez and Hugli, 1976).

It is thought that $\mathrm{C} 5 \mathrm{a}$ des arg is the most important and active physiological chemotactic factor. As such, it has been shown to elicit various pro-inflammatory reactions which can be either beneficial or detrimental to the host. The use of highly purified $\mathrm{C5}$ a des arg is critical for elucidating the roles and the mechanisms of action of this factor in these reactions as well as to rule out possible modulating effects of other serum proteins. Indeed, the use of purified C5a and C5a des arg has led to the discovery of receptors on human neutrophils (Chenoweth and Hugli, 1980) and has allowed for the elucidation of the intricate control mechanism for anaphylactic activity contained in C5a (Bokisch and Müller-Eberhard, 1970; Gerard and Hugli, 1981).

In addition to its relative simplicity and rapidity, the purification scheme presented in this report has other advantages. Serum depleted of C5a des arg by passage over the immunoadsorbent column has been substituted for untreated human serum in the chemotaxis under agarose assay resulting in significantly lowered random neutrophil migration (Manderino et al., 1981). A further advantage is that the antibody reacts with both $\mathrm{C} 5 \mathrm{a}$ and $\mathrm{C} 5 \mathrm{a}$ des arg which should allow purification of either molecule depending on the starting material. Lastly, the immunoadsorbent column can be recycled repeatedly, thus one column suffices for multiple purifications. These attributes make this method a practical alternative to the previously published procedures for purifying $\mathrm{C} 5 \mathrm{a}$ des arg or $\mathrm{C} 5 \mathrm{a}$. 


\section{References}

Bokisch, V.A., H.J. Müller-Eberhard and C.G. Cochrane, 1969, J. Exp. Med. 129, 1109.

Bokisch, V.A. and H.J. Müller-Eberhard, 1970. J. Clin. Invest. 49, 2427.

Chenoweth, D.E. and T.E. Hugli, 1980, Mol. Immunol. 17, 151.

Cochrane, C.G. and H.J. Müller-Eberhard, 1968, J. Exp. Med. 127. 371.

Craddock, P.R., D. Hammerschmidt, J.G. White, A.P. Dalmasso and H.S. Jacob, 1977. J. Clin. Invest. 60. 260.

Cuatrecasas, P., M. Wilcheck and C.B. Anfinsen, 1968, Proc. Natl. Acad. Sci. U.S.A. 61, 636.

Fantone, J., R.M. Senior, M.A. Kreutzer and P.A. Ward, 1979, J. Lab. Clin. Med. 93, 17.

Fernandez, H.N. and T.E. Hugli, 1976, J. Immunol. 117, 1688.

Fernandez, H.N. and T.E. Hugli, 1978, J. Biol. Chem. 253, 6955.

Gerard, C. and T.E. Hugli, 1981, Proc. Natl. Acad. Sci. U.S.A. 78, 1833.

Goetzl, E.J. and K.F. Austen, 1974, J. Clin. Invest. 53, 591.

Goldstein, I.M. and G. Weissmann, 1974, J. Immunol. 113, 1583.

Goldstein, I.M., S. Hoffstein, J. Gallin and G. Weissman, 1973, Proc. Natl. Acad. Sci. U.S.A. 70, 2916.

Goldstein, I.M., D. Roos and H.B. Kaplan, 1975, J. Clin. Invest. 56, 1155.

Gray, G.D., M.M. Mickelson and J.A. Crim, 1969, Immunochemistry 6, 641.

Henson, P.M., B. Zanolari, N.A. Schwartzman and S.R. Hong, 1978, J. Immunol. 121, 851.

Hugli, T.E. and H.J. Müller-Eberhard, 1978, Adv. Immunol. 26, 1.

Kunkel, S.L., D.L. Kreutzer, S. Goralnick and P.A. Ward, 1980, J. Immunol. Methods 35, 337.

Manderino, G.L., A.F. Suarez, A.A. Hirata and P.A. Ward, 1981, J. Immunol. Methods 45, 283.

Segrest, J.P., R.L. Jackson, E.P. Andrews and V.T. Marchesi. 1971, Biochem. Biophys. Res. Commun. 44, 390.

Segrest, J.P. and R.L. Jackson, 1972, in: Methods in Enzymology, Vol. 28, ed. V. Ginsburg (Academic Press, New York) p. 54.

Shin, H.S., R. Snyderman, E. Friedman, A. Mellors and M.M. Mayer, 1968, Science 162, 361.

Vallota, E.H. and H.J. Müller-Eberhard, 1973, J. Exp. Med. 137, 1109.

Vogt, W., 1968, Biochem. Pharmacol. 17, 727.

Ward, P.A. and L.J. Newman, 1969, J. Immunol. 102, 93.

Weber, K., J.R. Pringle and M. Osborn, 1972, in: Methods in Enzymology, Vol. 26, eds. C.H.W. Hirs and S.N. Timasheff (Academic Press, New York) p. 3. 